\title{
Observation and modelling of natural retention structures in the English Channel
}

\author{
Alain Ménesguen ${ }^{*}$, and Francis Gohin ${ }^{\mathrm{a}}$ \\ aáépartement Dynamiques de l'Environnement Côtier, Laboratoire Ecologie benthique, \\ IFREMER/Centre de Brest, 29280 Plouzané, France \\ *: Corresponding author : tel: 33298224334 ; fax: 33298224548 ; e-mail: amenesg@ifremer.fr
}

\begin{abstract}
:
Accumulation of heat, or dissolved substances (nutrients, pollutants, etc.), or fine suspended particles in a water body is a key process in the functioning of aquatic ecosystems and their resistance to perturbations. In complex and wide open environments such as marine ecosystems, net accumulation is not only linked to the local renewal capacity of the water body, but also to the partial recirculation of water due to convective cells of various sizes. The English Channel, which can be considered as mainly dominated by tidal movements, exhibits such a complex quasi-permanent long-term circulation, made of a central "river" bordered with a lot of nested gyres. Here, we show that structures visible on satellite images of SST (Sea Surface Temperature), chlorophyll and SPIM (Suspended Particulate Inorganic Matter) can be explained by steady state distributions of tracers having various half-life durations, which can be computed using a simple technique of regularly distributed micro-injection in the permanent flow field. Gyres induced by capes in open water appear to be retention areas, whereas gyres around islands (Channel Isles) appear to be strong disseminating areas, acting as slings. Moreover, SST satellite maps can be explained by a short-lived tracer during the "transitory" seasons (spring and autumn), and by a long-lived one during the "stable" seasons (summer and winter): long-term accumulation structures become apparent only in August and March. SPIM can be considered as a tracer injected only in muddy areas by the bottom friction caused by the swell, and having a half-life duration linked to the turbulent energy dissipation, which controls the settling rate; this succeeds to explain the observed turbidity in the central Channel essentially, as well as the striking asymmetry visible on images between the large turbid coastal band along the English coasts (materializing a natural long-term retention area), and the rather clear waters along the French coasts. The annual mean chlorophyll distribution in the Channel, as derived from satellite reflectance, can be simulated by a short-lived tracer injected proportionally to the mean light availability along the water column. Computing steady state distributions of various substances or particles in permanent circulation gives a simple and quick tool for understanding their mean stable distribution patterns in the oceans.
\end{abstract}

Keywords: English Channel; Steady state model; Tidal residual circulation; Retention structures; SST; Chlorophyll; Suspended Particulate Matter; Remote sensing 


\section{Introduction}

Ecologists have observed for a long time that phytoplankton biomass visible in water bodies depends not only on basic material (nutrients) and energy (light) supply, but also on the residence time of the water and its biogeochemical contents in the area under concern. Basically, a mean residence time is defined by the ratio of a volume to the flow rate going through it. Because the volume under concern is quite evident in completely mixed experimental reactors or in natural small lakes, much theory has been derived for the productivity of such semi-closed systems since the pioneer work of Monod(1950) and Vollenweider(1975). But the growing concern about eutrophication of some specific open coastal areas in the world, such as the eastern North Sea, the northern Adriatic, or the Vilaine bay in France, requests the extension of the residence time paradigm to the open sea and, hence, a sound definition of the relevant volumes that can be delineated in open fluid flows is needed. As a first step towards this aim, this paper proposes a simple numerical technique able to reveal the different volumes accessible to substances exhibiting different half-life characteristics. Validation of such a technique requires measured synoptic maps of various substances, with complete coverage of the area, and the finest available resolution. Only satellite imagery can bring such data at sea, at least for the surface layer. Therefore, this technique has been applied to a shelf sea of about $500 \mathrm{~km}$ x $200 \mathrm{~km}$, the English Channel, which provides various types of flow patterns created by the eastward tide propagation on irregular bathymetry. This shelf sea, with depths not exceeding $100 \mathrm{~m}$, except in the narrow central paleovalley of the Seine river, is characterized by a very strong tidal regime, which maintains a stable pattern of long term circulation, whatever the changing meteorological forcing. This so-called tidal residual circulation is now well known, mainly thanks to hydrodynamical models (see Methods). It is characterized by a central "river" flowing eastwards from the Atlantic to the North Sea (Fig.1), bordered with a lot of nested gyres, some of them being cape induced (Barfleur and Antifer along the French coast, Isle of Wight and Dungeness along the British coast), the others being centered on islands which the periodical flow must get around ; these last gyres can be very strong around the Channel Isles (Guernsey, Jersey, Alderney, Chausey...). As far as remote sensing is concerned, the English Channel area is now well documented, particularly since the launch of SeaWiFS (Sea Wide Field Sensor) at the end of 1997. Other authors have used, very early, satellite maps of the sea surface temperature or spectral reflectance to explain physical patterns, as the tidal fringes around the Channel Isles (Pingree et al., 1985), or the phytoplankton distribution in frontal zones (Viollier et al., 1987) but the instruments now in space give us a considerable set of new data. The question arises if the rotating, nested cells of various sizes embedded in the general eastward flow, which are observed on the images, may act as partially isolated volumes, able to accumulate pelagic substances, pollutants, or marine larvae, or phytoplankton which may lead to "red tides" in case of efficient retention in shallow, nutrientenriched areas. The hypothesis being tested in this paper is that some strong features appearing on satellite images can be explained by the spatially distributed retention or dispersion capabilities of the tidal residual circulation, as revealed by a simple $2 \mathrm{DH}$ modelling technique.

\section{Material and methods}

\subsection{Tidal residual flow field}

The long-term drift of particles on a macrotidal shelf such as the English Channel can be successfully estimated by the field of tide-filtered streams. The basic information lies in 2D horizontal fields of barotropic currents computed every minute during a tidal period $(12 \mathrm{~h} 25 \mathrm{mn})$, for a medium tidal amplitude. The simplest, and built-in conservative method for 
computing a residual flow field is the eulerian approach, i.e. to sum separately the flows through each mesh during a whole tidal period ; but, as pointed out by several authors (Pingree and Maddock, 1985, Orbi and Salomon, 1988), real long-term drift (Fig.1) is more accurately computed using a residual flow field deduced from lagrangian trajectories. Salomon and Breton (1991) have explained how they computed such a field for the English Channel, starting from a 2DH barotropic model of tidal currents based on ADI scheme applied to a C-type Arakawa grid (Fig.2). For regularly spaced departure points and regularly spaced departure times covering a $12 \mathrm{~h} 25 \mathrm{mn}$ tidal period, the residual displacement of a water particle after $12 \mathrm{~h} 25 \mathrm{mn}$ is computed and this vector is placed at the barycentre of the trajectory. A unique residual velocity field is then computed by merging these numerous elementary residual displacements. Here, we will use the flow field they obtained under a constant mean tidal regime and a permanent uniform wind field (SSW, $6.2 \mathrm{~m} . \mathrm{s}^{-1}$ ), which gives a permanent eastward residual flow rate about $120000 \mathrm{~m}^{3} \cdot \mathrm{s}^{-1}$ through the Dover Strait Salomon and Breton (1993).

\subsection{Steady state distribution of a tracer in a permanent fluid flow}

For the English Channel, according to the C-type Arakawa discretisation scheme (Fig.2), the permanent lagrangian residual flow field can be represented on a regular grid $(\mathrm{nc}=367$ columns $\times \mathrm{nr}=184$ rows, mesh : $1852 \mathrm{~m} \times 1852 \mathrm{~m}$ ), by its longitudinal component (velocity $\mathrm{Ux}_{\mathrm{i}, \mathrm{j}}$ applied to the vertical mesh wall having a depth $\mathrm{Hx}_{\mathrm{i}, \mathrm{j}}$ and a width $\mathrm{Lx}_{\mathrm{i}, \mathrm{j}}$ ) and its latitudinal component (velocity $\mathrm{Vy}_{\mathrm{i}, \mathrm{j}}$ applied to the vertical mesh wall having a depth $\mathrm{Hy}_{\mathrm{i}, \mathrm{j}}$ and a width $L y_{i, j}$ ). Using an upstream, first order advection scheme applied to a uniform grid with square meshes $\left(\mathrm{Lx}_{\mathrm{i}, \mathrm{j}}=\mathrm{Ly}_{\mathrm{i}, \mathrm{j}}\right.$, for all $\mathrm{i}$ and $\left.\mathrm{j}\right)$, all these flow rates can be gathered in a unique square ( $\mathrm{nr} \times \mathrm{nc}, \mathrm{nr} \times \mathrm{nc}$ ) matrix, the so-called advective transport matrix $\mathrm{A}$, according to the following equations established for the mesh situated at row $i$ and column $j$ in the grid :

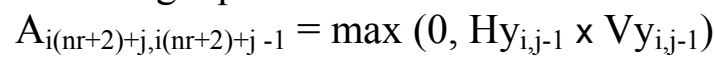

$\mathrm{A}_{\mathrm{i}(\mathrm{nr}+2)+\mathrm{j}, \mathrm{i}(\mathrm{nr}+2)+\mathrm{j}+1}=-\min \left(0, \mathrm{Hy}_{\mathrm{i}, \mathrm{j}} \times \mathrm{Vy}_{\mathrm{i}, \mathrm{j}}\right)$

$\mathrm{A}_{\mathrm{i}(\mathrm{nr}+2)+\mathrm{j},(\mathrm{i}-1)(\mathrm{nr}+2)+\mathrm{j}}=\max \left(0, \mathrm{Hx}_{\mathrm{i}-1, \mathrm{j}} \times \mathrm{Ux}_{\mathrm{i}-1, \mathrm{j}}\right)$

$\mathrm{A}_{\mathrm{i}(\mathrm{nr}+2)+\mathrm{j},(\mathrm{i}+1)(\mathrm{nr}+2)+\mathrm{j}}=-\min \left(0, \mathrm{Hx}_{\mathrm{i}, \mathrm{j}} \times \mathrm{Ux}_{\mathrm{i}, \mathrm{j}}\right)$

$\mathrm{A}_{\mathrm{i}(\mathrm{nr}+2)+\mathrm{j}, \mathrm{i}(\mathrm{nr}+2)+\mathrm{j}}=\min \left(0, \mathrm{Hy}_{\mathrm{i}, \mathrm{j}-1} \times \mathrm{Vy}_{\mathrm{i}, \mathrm{j}-1}\right)-\max \left(0, \mathrm{Hy}_{\mathrm{i}, \mathrm{j}} \times \mathrm{Vy}_{\mathrm{i}, \mathrm{j}}\right)+\min \left(0, \mathrm{Hx}_{\mathrm{i}-1, \mathrm{j}} \times \mathrm{Ux}_{\mathrm{i}-1, \mathrm{j}}\right)-\max$ $\left(0, \mathrm{Hx}_{\mathrm{i}, \mathrm{j}} \times \mathrm{Ux}_{\mathrm{i}, \mathrm{j}}\right)$

Natural boundary inflows appear in this advection matrix at every marine cell of the border associated to an entering residual current, and at the coastal meshes receiving a river. If we call Clim the vector of permanent tracer concentrations imposed in all these boundary inflows (this vector has $\mathrm{nr} \times \mathrm{nc}$ rows, but contains zeroes except at boundary meshes having an entering flow rate), the steady state distribution of a conservative tracer concentration should be obtained by solving the system:

Cequil $=\mathrm{A}^{-1}$.Clim

Two problems then arise, a mathematical one and a numerical one.

First, the advective transport matrix is singular as soon as one completely closed loop does exist in the advective field, the simplest case being a single mesh totally closed. A simple way to make A always non-singular, even if terrestrial meshes are included, is to add into every mesh a very small flow rate (coming from outside of the system) and to take out the same flow rate from the mesh, say $f_{i, j}$ for the $(i, j)$ mesh: $f_{i, j}$ can be seen as an additional flow passing through the mesh orthogonally to the real horizontal flow field. If we name $\mathrm{Cf}$ the input tracer concentration imposed in this additional flow, the corresponding tracer flow entering the system at the $(i, j)$ mesh will be : $f_{i, j} . C f_{i, j}$, the tracer flow going outside of the system at the $(i, j)$ mesh will be $\mathrm{f}_{\mathrm{i}, \mathrm{j}}$.Cequil $\mathrm{i}_{\mathrm{i}, \mathrm{j}}$. The field of additional flows $\mathrm{f}_{\mathrm{i}, \mathrm{j}}$ may be defined in different arbitrary manners, according to the type of tracer under consideration and the purpose of the calculus. If we name $S_{i, j}$ the horizontal surface of $(i, j)$ mesh and $V_{i, j}$ the volume of the water column 
associated to the same mesh, we can use surficial small flows (i.e. $f_{i, j}=10^{-6} \cdot S_{i, j}$ ) for tracers emitted really by the air-sea interface or by the sea-bottom one, or volumic small flows (i.e. $f_{i, j}$ $=10^{-6} \cdot \mathrm{V}_{\mathrm{i}, \mathrm{j}}$ ) for tracers emitted in the whole water column; here, we used the surficial type only.

The second problem is linked to the handling of huge matrices: in our Channel application, the square matrix A has 67528 rows, and its direct inversion on a personal computer is nearly unfeasible. Here we developed an iterative method based on splitting the original linear system into a mosaic of partially recovering subsystems. The size of the basic grid block has been set to $11 \mathrm{x} 11$, so that inversion of all the corresponding $121 \mathrm{x} 121$ submatrices becomes easy and fast on a personal computer; due to the fact that any grid block provides its border columns and rows as boundary conditions for the four adjacent blocks, information between adjacent subsystems circulates in the overall solution from an iteration to the next, building a converging good approximation of the solution after 50 iterations (Fig.3).

\subsection{Sources and sinks of tracers used for temperature, SPIM and chlorophyll}

Various input tracer concentration fields $\mathrm{Cf}$ may be used. For instance, Boolean-type concentration fields are relevant for simulating dilution of tracers coming from local pointsources (i.e. $\mathrm{Cf}_{\mathrm{i}, \mathrm{j}}>0$ for the mesh containing the point-source, $\mathrm{Cf}_{\mathrm{i}, \mathrm{j}}=0$ elsewhere).

For simulating transitory air-sea heat exchange, we used a uniform concentration field (i.e. $\mathrm{Cf}_{\mathrm{i}, \mathrm{j}}=1$ for all $\mathrm{i}$ and $\mathrm{j}$ ).

To simulate Suspended Particulate Inorganic Matter (SPIM), we used a concentration $\mathrm{Cf}_{\mathrm{i}, \mathrm{j}}$ proportional to the silt content of the bottom sediment, and to the bed shear stress caused by the mean swell (i.e. to the square of the mean significant swell height divided by the depth). In the case of chlorophyll simulation, the corresponding tracer has to be introduced linked to the potential local richness in nutrients and to the mean availability of light among the water column. The light at sea surface level has been considered as uniform $\left(\mathrm{I}_{0}=400 \mathrm{~W} . \mathrm{m}^{-2}\right)$, but suspended inorganic particulate matter (SPIM) and nutrient richness (N) cannot be assumed as spatially uniform. For SPIM, the mean annual field was obtained from SeaWiFS satellite data, averaged over the 1998-2003 period. For N, arguing from the predominant nitrogen limitation of primary production in the Channel (Hoch and Ménesguen, 1997), only dissolved inorganic nitrogen was considered, in form of its steady state winter conservative distribution. This was obtained by the present model forced by an open ocean inflow concentration of 3 $\mu$ mol.L $L^{-1}$, (deduced from surface nitrate measurements made by Morin et al. (1991) at the south-western entrance of the English Channel), and a local additional flow concentration $\mathrm{Cf}_{\mathrm{i}, \mathrm{j}}$ $=0$ for all $\mathrm{i}$ and $\mathrm{j}$, except in the meshes receiving river outflows. In order to approximate real loadings, all river nitrate concentrations were set to $500 \mu \mathrm{mol} . \mathrm{L}^{-1}$, the maximum annual mean observed in the Seine river (Guillaud and Ménesguen, 1998); for the river k with mean annual flow rate $f_{k}$, the concentration of the additional flow $f_{i j}$ in the receiving mesh was assumed to be $\mathrm{Cf}_{\mathrm{i}, \mathrm{j}}=\left(500 . \mathrm{f}_{\mathrm{k}}\right) / \mathrm{f}_{\mathrm{ij}}$. If we assume a Michaëlis-Menten law for light dependence of growth (with half-saturation constant $\mathrm{K}_{\mathrm{I}}$ ) as well as for global inorganic nutriment richness (with half-saturation constant $\mathrm{K}_{\mathrm{N}}$ ), we can compute a rough mean growth limitation in a well-mixed water column of height $\mathrm{H}$ and mean SPIM content $\mathrm{M}$ and mean chlorophyll content $\mathrm{C}$ :

- at depth $\mathrm{z}$, the available light is : $\mathrm{I}_{\mathrm{z}}=\mathrm{I}_{0}$. $\exp (-\mathrm{k} . \mathrm{z})$, with the extinction coefficient increasing with the suspended inorganic particulate matter $M$ and the mean chlorophyll content $C: \mathrm{k}=\mathrm{k}_{0}$ $+\mathrm{k}_{1} \cdot \mathrm{M}+\mathrm{k}_{2} \cdot \mathrm{C}^{0.8}$ (Gohin et al., 2005)

- over the whole water column, the mean light limitation is :

$$
\frac{\ln \left[\frac{K_{I}+I_{0}}{K_{I}+I_{0} \cdot e^{-\left(k_{0}+k_{1} \cdot M+k_{2} \cdot C^{0.8}\right) \cdot H}}\right]}{\left(k_{0}+k_{1} \cdot M+k_{2} \cdot C^{0.8}\right) \cdot H}
$$


- the resulting mean growth rate of phytoplankton is :

$$
\mu=\mu_{\max } \cdot \frac{N}{K_{N}+N} \cdot \frac{\ln \left[\frac{K_{I}+I_{0}}{K_{I}+I_{0} \cdot e^{-\left(k_{0}+k_{1} \cdot M+k_{2} \cdot C^{0.8}\right) \cdot H}}\right]}{\left(k_{0}+k_{1} \cdot M+k_{2} \cdot C^{0.8}\right) \cdot H}
$$

Here, the parameter values considered as constant all over the domain were: PAR available at sea surface $\mathrm{I}_{0}=300 \mathrm{~W} / \mathrm{m}^{2}, \mathrm{k}_{0}=0.05 \mathrm{~m}^{-1}, \mathrm{k}_{1}=0.03 \mathrm{~m}^{-1} \cdot \mathrm{mg}^{-1} . \mathrm{L}, \mathrm{k}_{2}=0.05 \mathrm{~m}^{-1} \cdot \mu \mathrm{g}^{-1} \cdot \mathrm{L}, \mathrm{K}_{\mathrm{I}}=50 \mathrm{~W} \cdot \mathrm{m}^{-2}$, $\mu_{\max }=1.5 \mathrm{day}^{-1}$. The constant concentration of phytoplankton in the open ocean inflow was set to $0.5 \mu \mathrm{g} / \mathrm{L} \mathrm{Chl.a,} \mathrm{following} \mathrm{the} \mathrm{values} \mathrm{occurring} \mathrm{in} \mathrm{the} \mathrm{south-western} \mathrm{entrance} \mathrm{of} \mathrm{the} \mathrm{English}$ Channel in our satellite-derived mean annual concentration map of chlorophyll (see Fig. 10a). In order to take into account non-conservative properties, tracers can be considered as having a first order decay, with a specific half-life duration $T$. In our case, homogeneous $T$ values all over the Channel have been retained for temperature, whereas spatially varying values have been necessary to simulate SPIM and chlorophyll distributions.

For SPIM, as 0.5 m.day $^{-1}$ can be considered to be a minimum net settling velocity of silt particles in the central most turbulent part of the English Channel, where the mean depth is about $60 \mathrm{~m}$, the maximum half-life duration $\mathrm{T}$ is then about $\operatorname{Ln}(2) /(0.5 / 60)=20.79$, and has been set to 20 days. The local half-life duration $T_{i, j}$ in the $(i, j)$ mesh was then considered as varying linearly between 0 and 20 days depending on the kinetic turbulent energy dissipation criterium $\mathrm{U}^{3} / \mathrm{H}$, where $\mathrm{U}$ is the mean instantaneous current velocity over a tidal period.

$$
T_{i, j}=20 \cdot \frac{\frac{\left(U_{i, j}\right)^{3}}{H_{i, j}}}{\operatorname{Max}_{i, j}\left[\frac{\left(U_{i, j}\right)^{3}}{H_{i, j}}\right]}
$$

For chlorophyll, the decay rate has been considered as made of two components: a spatially uniform one, corresponding to pure pelagic mortality processes (with a half-life set to 4 days) and a spatially varying one, corresponding to the probability of settling on the bottom and to be consumed by benthic filter-feeding. As a first approximation, this component has been set inversely proportional to the water depth $\mathrm{H}$ (mortality rate $\left(\right.$ day $\left.^{-1}\right)=10 / \mathrm{H}, \mathrm{H}$ in meters).

\subsection{Satellite image processing}

The Sea Surface Temperature (SST) maps of the Channel are derived from AVHRR (Advanced Very High Resolution Radiometer) data. These maps have been provided by the SAF (Satellite Application Facility) "Ocean and Sea Ice" of EUMETSAT/MeteoFrance, located in Lannion (France). The surface chlorophyll a concentration in the English Channel has been routinely retrieved from the SeaWiFS reflectance by using a look-up table specifically defined for these turbid waters (Gohin et al., 2002). This method is based on the Blue/Green reflectance ratio, as defined in the standard OC4 algorithm ( O'Reilly et al., 1998) for clear waters, but takes also into account the reflectance at 412 and $555 \mathrm{~nm}$ in order to empirically correct, as much as possible, for errors in the atmospheric correction, yellow substances and mineral sediment effects. This table gives much lower and more realistic results than OC4 during the winter months and in the river plumes in case of high concentrations of suspended sediments. Once the chlorophyll concentration has been determined, SPIM, which is defined as the SPM not related to the dead or alive endogenous phytoplankton, is derived from the radiance in the green, at $555 \mathrm{~nm}$. SPIM is assessed by inverting a semi-analytic model of the radiative transfer taking into account the theoretical 
absorption and diffusion coefficients of the different components of the medium (pure water, phytoplankton and SPIM) at $555 \mathrm{~nm}$ (Gohin et al., 2005). This method provides realistic estimations of concentrations of chlorophyll and SPIM over the continental shelf all over the year. The only significant limitation in the reliability of these images stands for SPIM, which may be underestimated in case of high chlorophyll concentrations and in the most turbid areas (where the channel at $670 \mathrm{~nm}$ should be preferred). The best images obtained from January 1998 to December 2003, whose percentage of cloud-free pixels was above a threshold of $25 \%$, have been used to calculate the average map. Average maps are calculated on a Mercator grid with a pixel size of $1100 \mathrm{~m}$. On each pixel of the grid, the mean value is the arithmetic mean of all the satellite-derived Chl.a or SPIM observed during the period.

\section{Results}

\subsection{The theoretical location of the retention areas in the English Channel}

Continuous injection of a conservative tracer into every mesh of the stable tidal lagrangian residual velocity field allows highlighting different water bodies in the English Channel (Fig.4). Apart from the main eastward central flow, which appears gradually enriched in tracer from west to east, several gyres appear as tracer abnormally concentrating water bodies, due to recirculation. Some capes induce well individualized gyres: Barfleur gyre (Fig.4 A) and Antifer gyre (Fig.4 B), some bathymetric coastal features create small coastal gyres which can remain isolated: Luc-sur-mer (Fig.4 C), Port-en-Bessin (Fig.4 D), Erquy (Fig.4 E), or aggregate into large retention areas: for instance, Portland (Fig.4 F), Isle of Wight west (Fig.4 G), south (Fig.4 H) and east (Fig.4 I) and Eastbourne (Fig.4 J) gyres merge into a south-England coastal strip. A particular strong feature appears along the French coast of the eastern Channel, as a narrow, alongshore strip (Fig.4 K) starting from the Antifer gyre and ending at Cape Gris Nez; even a pure 2D barotropic field of residual currents without any density effect of freshwater inputs, because it guides water in a shallow, alongshore strip and locally re-circulates it in micro-gyres, is then sufficient to explain the observed so-called "fleuve côtier" (Brylinski et al., 1996). Shoals can also generate some trapping, as around Eddystone Rocks (Fig.4 L) or in the large area northwest from Roches Douvres (Fig.4 M). Surprisingly, the strongest gyres, which are generated by the tidal motion rotating around islands, induce only a medium accumulation: Jersey (Fig.4 N), Chausey (Fig.4 P) or even a local depuration: Guernsey (Fig.4 Q), Alderney (Fig.4 R) and Scilly (Fig.4 S); the first four are cyclonic, the latest anti-cyclonic. Two types of gyre do appear, whatever their cyclonic or anti-cyclonic nature: "open water" gyres, which can accumulate conservative tracers, and "around islands" gyres, which act on the contrary as slings projecting tracers outwards. The behaviour of a specific gyre can be visualized through the steady state plume obtained by injecting a strong additional flow with concentration 1 in a single mesh in the middle of the gyre and very weak additional flows with concentration 0 elsewhere. Figure 5 shows the containing behaviour of an open water gyre (Barfleur) and the dispersive behaviour of an around island gyre (Guernsey). The case of Jersey is similar to Guernsey, except that the projected tracer quickly invades a rectangular area (the so-called Gulf of Saint-Malo) but is contained offshore by the front between Jersey and Guernsey.

But all the retention structures observed by using a pure conservative tracer are not of the same nature, especially in terms of time constant. Using tracers having increasing half-life constants allows screening the "quick" structures from the "slow" ones. Figure 6 shows that a quick disappearing substance (half-life $\mathrm{T}=0.5$ day) cannot "see" any of the retention areas previously described : as the substance is injected proportionally to the sea surface, steady state concentration distribution closely reflects the local dilution volume, i.e. the depth of the 
grid meshes. This explains the higher concentration in zones with depths between 0 and 20m, i.e. in a narrow strip along the coasts, but also around Chausey Isles (P on Fig.4) and between Jersey (N on Fig.4) and the French coast. Substances having half-life durations about 4 days can be accumulated in small gyres such as Luc-sur-mer (C on Fig.4), Port-en-Bessin (D on Fig.4), Erquy (E on Fig.4), Isle of Wight west (G on Fig.4) and east (I on Fig.4). A two weeks half-life duration is necessary to Barfleur (A on Fig.4), Antifer (B on Fig.4) or south Isle of Wight ( $\mathrm{H}$ on Fig.4) to become apparent, as well as the alongshore "fleuve côtier" (K on Fig.4). A one month half-life duration brings the completeness of these previous structures and begins merging some of them, as along the coast of England. But some striking structures exhibited by a totally conservative tracer on Fig. 4 are not yet fully developed in the $\mathrm{T}=32$ days case: the $65 \mathrm{~m}$ deep area north to the "Banc des langoustiers" (T in Fig.4) does work as a retention area for quasi-conservative substances only, as do the inner part of Antifer gyre (B on Fig.4), the southern boarder of the Portland-Wight-Eastbourne belt, and the small Eddystone Rocks area (Fig. 4 L). These non-uniform dynamics of the various retention areas in the Channel will be of great concern for numerous ecological properties : accumulation of short-lived particles such as phytoplankton will be efficient in only few and restricted areas, whereas medium-lived particles such as macro-zooplankton or invertebrates larvae can be trapped in mesoscale structures. Only nearly conservative substances, such as persistent pollutants (PCB, heavy metals...) can reveal the slowest retention structures, such as the middle of the Antifer gyre in the Eastern Channel or the "Banc des langoustiers" area in the western Channel.

\subsection{Detection of these theoretical areas of retention on satellite-derived maps}

SST in the Channel is one of the most anciently and extensively measured of all the oceanographic parameters. The most striking features are the chevron structure of surface isotherms in the central and eastern parts, along with the creation, every spring, of a warmer surface layer in the stratified north-western part of the Channel, separated from the wellmixed central Channel by a well-marked front. As we don't use a multilayer model in this paper, our only purpose here is to assess how structures in the unstratified parts of the Channel can be explained by the computed retention areas. For each season, a clear AVHRR image of the whole Channel has been chosen; left column of Fig.7 shows these pictures. If we assume that the instantaneous net thermal exchange between the sea and the atmosphere is globally homogeneous all over the Channel, these SST maps should be simulated by our technique of continuous injection into every mesh of a conservative tracer having a specific half-life duration. In order to find the half-life best fitted to each season, the 8 theoretical maps corresponding to tracers having respectively half-life constants $\mathrm{T}=2^{0}, 2^{1}, 2^{2}, 2^{3}, 2^{4}, 2^{5}$, $2^{6}, 2^{\infty}$ days have been compared to the four seasonal satellite images, using the linear correlation between (satellite SST, tracer concentration) pairs all over the Channel grid in autumn and winter, only in the non-stratified part in spring and summer (Fig.8). Two types of situations came out of these comparisons: late summer and late winter situations are better simulated by tracer having long half-lives $\left(\mathrm{r}^{2}=0.36\right.$ and 0.54 respectively at $\left.\mathrm{T}=2^{\infty}\right)$, whereas spring and autumn situations are more correlated to very short-lived tracers $\left(r^{2}=0.31\right.$ at $\mathrm{T}=2^{2}$ for both). For each season, the right column of Fig.7 gives the best correlated tracer distribution, with tracer concentration set at 0 in the marine entrances and at 1 in the additional continuous injections made into every mesh for "heating" seasons (spring and summer) and the reverse for "cooling" seasons (autumn and winter). Accordingly, only "quick" retention areas can be seen in satellite SST images taken in transient seasons, for instance the warmer waters in spring and cooler ones in autumn in the small coastal gyres: Luc-sur-mer (Fig.4 C), Port-en-Bessin (Fig.4 D), Erquy (Fig.4 E), Isle of Wight east (Fig.4 I). On the contrary, "stable" seasons corresponding to several months of low (winter) or high 
(summer) thermal input can reveal "slow" retention areas, such as the Barfleur (Fig.4 A), Antifer (Fig.4 B) or south Isle of Wight (Fig.4 H) gyres, as well as the alongshore "fleuve côtier" (Fig.4 K) and the "Banc des langoustiers" area (Fig.4 T). These areas appear abnormally warm at the end of summer and abnormally cold at the end of winter. Areas with the longest time constant can even persist in the following transient seasons, as relics of the previous stable season: see the warm core staying on the "Banc des langoustiers" area (Fig.4 T) in the autumn image.

Turbidity of the sea surface waters is another oceanographic parameter of great concern for ocean optics and photosynthesis in the sea. Recent progress in sea colour satellite data processing allows to discriminate SPIM from organic and living components of the global turbidity. Despite the fact that SPIM is generally more concentrated near the bottom than near the surface of the water column, satellite images reveal the presence of SPIM in surface waters in some areas of the Channel, especially after wind episodes. In such an intermittent phenomenon, a mean composite image performed all over the clear SeaWiFS images available (Fig.9 left) has been preferred to some instantaneous images. This overall mean reveals two striking features: the opposition between the turbid central Channel and the rather clear western and eastern parts, the dissymmetry between the English coast (more turbid, especially in the south of Isle of Wight) and the French coast. The first feature reminds us to the well-known maximum of turbulent energy dissipation situated in the zone of maximum velocity of tidal currents, in the middle of the Channel between the French Cotentin peninsula and the Isle of Wight (Pingree, 1980). The permanent vertical mixing in this central region can prevent SPIM from sedimentation, i.e. locally lengthen their half-life constant, whereas non-turbulent areas will induce quick settlement, i.e. shorten SPIM half-life duration. The second feature is in favour of a re-suspension of fine particles being more sustained in the English coastal zone than in the French one. The map of sediments in the Channel (Vaslet et al., 1978) clearly shows more silty deposits along the England coast, especially in Lyme Bay, where the Channel biggest muddy area is located. In a steady state situation however, re-suspension of fine silts cannot be driven by tidal currents, because silts indeed settle in low current areas. Swell can then be invoked, especially in the western Channel impacted by waves coming from the Atlantic. Actually, thanks to computed maps of percentage of time of sediment disturbance by waves, Grochowski and Collins (1994) have shown that the most impacted areas were located on the French side, along the western coast of Cotentin peninsula ( $\geq 40 \%$ of the year), and along the English side, in the coastal strip of Lyme Bay and at the entrance of the Solent ( $\geq 20 \%$ of the year). A map of computed annual mean significant wave height (Benoit and Lafon, 2005) and a map of silty sediment fraction (Vaslet et al., 1978) in the Channel have then been combined to weigh the tracer concentration in the additional flow injected in every mesh. Tracer concentration in entering water at the western entrance has been set to zero. The steady state distribution of such a tracer (Fig.9 right) explains the main features of the observed maximum of the mean annual SPIM distribution in the central Channel (Fig.9 left): in the southern area, between Channel Isles and the Cotentin, silty deposits in shallow waters are re-suspended by the swell, and the suspended particles which enter the strong residual gyres around Channel Isles are maintained in the water column and projected all around, building the plume of turbid waters extending northerly from the Cotentin peninsula. On the contrary, the striking turbidity maximum in the south of Isle of Wight can be explained by trapping particles coming from the Lyme Bay area (Devon), or from the western approach of the Solent, by the open water gyre located in the strong current area in the south of Isle of Wight (Fig.4 H). Observed SPIM distribution illustrates very well the opposite functioning of open water gyres and around island ones.

Chlorophyll content (Chl) of the surface waters is now well estimated from satellite colour sensors, even in the coastal zone. As for SPIM, Chl images show the sporadic and 
spatially heterogeneous behaviour of the phytoplankton growth throughout the seasons; according to our steady state point of view, only the mean composite image (Fig.10 left) will be considered here. The more striking features of this Chl distribution are the poorness of the Western Channel, except in the north-western part, where the summer stratification allows annual blooming (Pingree et al., 1979, Holligan et al., 1983) of a particular dinoflagellate, Karenia mikimotoï, and the richness of a strip along the French coast of eastern Channel, including the Barfleur (Fig.4 A) and Antifer (Fig.4 B) gyres and the "fleuve côtier" (Fig.4 K). Comparatively, the strip of enhanced $\mathrm{Chl}$ content also noticeable along the England coast, from the east of Isle of Wight up to Eastbourne, appears thinner and poorer. That could be referred to the dissymmetry of river loadings along the English and the French borders: only the last one receives important nutrient loadings by the rivers Seine and Somme. As the injection technique in every mesh allows the computation of the steady state distribution of any nutrient considered as a pure conservative tracer, here we have chosen to take into account only the main limiting nutrient for phytoplankton growth, i.e. nitrogen, introduced in the Channel by the Atlantic oceanic water and by the main 16 French and English tributaries. This computed steady state nitrate distribution can be considered as giving the winter initial richness of the Channel, which will fuel the phytoplankton production all over the year, as "new" nutrient form at the beginning of spring and as "regenerated" nutrient form during summer and autumn. The number of cycles experienced during one year by a nitrogen atom will vary from 0 (at the mouth of rivers) to 5 (Maguer et al., 1996) in poor marine areas of the western Channel, so that either loading forcing at the boundaries or intense recycling in oceanic areas may be considered as maintaining the order of magnitude of nutrient richness fairly constant at the year level. This nutrient map can then be used in the Michaëlis nutrient limiting factor weighing the continuous injection of phytoplankton made into every mesh as detailed in equation (3). As the extinction coefficient is not only dependent on the SPIM turbidity (Fig.9 left) but also on the unknown phytoplankton biomass, the final system to be solved for chlorophyll concentrations becomes nonlinear, but can also be solved by our iterative method. Surprisingly, the best fitted computed steady state chlorophyll distribution (Fig.10 right) was obtained without any nutrient limitation $\left(\mathrm{K}_{\mathrm{N}}=0\right)$ and a moderate light limitation $\left(\mathrm{K}_{\mathrm{I}}=50 \mathrm{~W} \cdot \mathrm{m}^{-2}\right)$; the corresponding steady state reproduces very well the patterns of mean chlorophyll in the Eastern Channel and along the U.K. coast, but fails in two areas of the Western Channel. Because of the inability of this 2D model to take into account the summer stratification in the north-western Channel, the Karenia bloom cannot be reproduced. Taking into account a mortality component growing inversely to depth does not totally prevent the model from overestimation of the phytoplankton concentrations occurs around the Channel Isles Jersey and Chausey. This could be explained by the strong predation exerted in this special area of the English Channel by the very abundant shellfish populations (Savina, 2004).

\section{Discussion}

The steady state calculus has been applied here to a $2 \mathrm{D}$ permanent flow in an unstratified water body. Obviously, this restriction hampers the computation of realistic maps in the thermally stratified areas, such as the north-western English Channel in summer. As areas able to stratify can be delineated by a critical isoline of the Simpson-Hunter criterion (Simpson and Hunter, 1974), a possible improvement could be obtained by splitting the whole domain in two layers (e.g. the surface layer going from the sea surface down to $20 \mathrm{~m}$ deep, and the bottom layer beneath). These superposed layers should be coupled by vertical diffusive exchange (low in the stratified area, strong in the well-mixed area). The main 
problem to be solved is the determination of the concentration of the micro-injection in a bottom mesh relatively to the concentration injected in the surmounting surface mesh.

For SPIM studies, our technique can help explaining the origin of suspended material observed in some places, as in the gyre south from the Isle of Wight. Velegrakis et al. (1999) have shown, by measurement of size and diatom material content of the SPIM in the central English Channel, that the turbidity maximum in the south of Isle of Wight was probably fuelled not by local re-suspension, but by fine particles coming from the coastal zone and transported there by horizontal advection; as a matter of fact, fine particles are absent in the coarse grained sediments under the patch of turbidity, or trapped under the armour formed by these coarse gravels. Using a 2D hydrodynamical model containing a wave/current interaction formulation, they also showed that coastal re-suspension can effectively be caused by westerly waves reaching the English coast. Our technique shows that a permanent turbid patch can be formed by trapping allochtonous fine particles in an "open water" gyre, and could be used for assessing the parts of various coastal places in the total fuelling of this turbid patch.

For phytoplankton, the fact that observed annual patterns can be well reproduced by taking into account the only light limitation, is in favour of the pre-eminence of the light availability in the control of primary production in the English Channel, at least at the annual scale. The steady state approach corroborates the results of the dynamic modelling, as presented on a 15 year period by Hoch and Ménesguen (1997). In the coastal areas, the apparent lack of nutrient limiting effect at the yearly level can be explained by the terrestrial loadings, especially in the eastern French coastal strip by the Seine and Somme loadings. The coastal turbidity due to river inputs as well as sediment re-suspension by waves militates also in favour of a main limitation by light in these areas. On the contrary, the non-emergence of the nutrient limitation as the main one in the deep central and western Channel appears more questionable. As previously discussed, our 2DH model cannot represent the vertically varying nutrient availability in the summer stratified north-western Channel, and cannot bring a reliable answer for this particular area. But in the well-mixed central Channel, if we take a representative set of parameter values (depth $=60 \mathrm{~m}$, mean chlorophyll concentration $=0.6 \mu \mathrm{g} / \mathrm{L}$, mean SPIM concentration $=1 \mathrm{mg} / \mathrm{L}$ ), the light limitation factor according to Eq. 2 amounts to 0.285 , a limitation which would be overridden by the nutrient limiting effect only if the phytoplankton would have a Michaëlis constant for nitrogen uptake $\mathrm{K}_{\mathrm{N}}>7.5 \mu \mathrm{mol} / \mathrm{L}$ in waters having the annual mean nitrogen concentration $\left[\mathrm{NO}_{3}\right]=3 \mu \mathrm{mol} / \mathrm{L}$, and $\mathrm{K}_{\mathrm{N}}>0.75 \mu \mathrm{mol} / \mathrm{L}$ in waters having the common summer level of nutrient $\left[\mathrm{NO}_{3}\right]=0.3 \mu \mathrm{mol} / \mathrm{L}$. As many authors (Harrison et al., 1996) have measured $\mathrm{K}_{\mathrm{N}}$ values lower than $1 \mu \mathrm{mol} / \mathrm{L}$ in temperate oceanic waters, it seems plausible that in sufficiently deep and well-mixed water column (i.e. about $50 \mathrm{~m}$ deep), such as the whole central English Channel, the light limitation is stronger than the nutrient one.

Using half-life constants adapted to planktonic larval stages of benthic species should also provide some explanation to the observed benthic adult geographical distributions, as well as their genetic homogeneity. As shown in Fig.5, a benthic species with a pelagic stage, either autochtonous or accidentally introduced, will be contained or rapidly disseminated, depending on the type of area where the pelagic stage is released. In the Bay of Seine (Eastern English Channel), some recent genetic studies (Jolly et al., 2003), as well as lagrangian simulations (Ellien et al., 2004), have confirmed the relative independence of populations of benthic annelids (Pectinaria koreni) located in different structures of retention, such as the Barfleur (Fig.4 A) and the Antifer (Fig.4 B) gyres. Conversely, long coastal strips as the "fleuve côtier" (Fig. $4 \mathrm{~K}$ ) have been shown to ensure a progressive transport of ageing larvae of annelids (Polydora ciliata, Brylinski and Lizon, 2002) or fishes (Sprattus sprattus, Grioche et al., 1999) along the whole French coast of the Eastern Channel. The standard retention 
pattern induced by the mean residual tidal circulation, as considered in this study, may be partially disturbed by the winds, inducing year-to-year fluctuations in the retention capability of some water masses and, hence, contributing to the recruitment fluctuations of benthic populations (Barnay et al., 2003, Lagadeuc, 1992, Ellien et al., 2004). However, coastal ecosystems such as the English Channel, where the retention process is mainly governed by the tidal factors, are expected to show a strong resilience to the climatic change.

\section{Conclusion}

Computed permanent flow fields seem to have never been used to calculate steady state distributions in marine areas. The technique proposed here allows exploring several problems, such as assessing steady state domain of influence of any point source (on the coast line or in high sea), or delineating accumulation areas. It should provide an hydrodynamically based method for splitting the sea in a mosaic of rather independent regions, which could improve ecological box-models (Ménesguen and Hoch, 1997, Baretta et al., 1995), as well as found on physical grounds any "administrative" water masses delineation, used for instance for water quality monitoring. In Europe especially, the Common Implementation Strategy of the Water Frame Directive (CIS, 2002) requires splitting the coastal area into significant water bodies, based on some "obligatory factors": latitude, longitude, tidal range, salinity, and some "optional factors": current velocity, wave exposure, mean water temperature, mixing characteristics, turbidity, mean substratum composition, water temperature range and retention time (of enclosed bays). The fact that the retention time parameter has been restricted to enclosed bays by the official guidance shows that the delineation of hydrodynamically relevant water bodies in open coastal waters remains undefined, although the delineation of coastal water masses is the necessary first step of monitoring coastal water quality in the Water Frame Directive.

Coupling a static benthic grid (i.e. without any horizontal transport) to the surmounting dynamical flow grid should allow a more complete study of pelago-benthic systems, as fine sediment deposition and re-suspension, or settlement of benthic species with planktonic larvae. The steady state computation appears to be a quick tool for testing the respective importance of different processes in the final mean geographical distribution of marine species. 


\section{Acknowledgements}

We thank J.C. Salomon and M. Breton (Seamer) for having provided the lagrangian residual flow field for the English Channel, P. Bailly du Bois (IRSN) for the map of silt fraction digitized from the Channel sediment map (Vaslet et al., 1978), and M. Benoit and F. Lafon (EDF/LNHE) for having provided their computed map of average swell significant height in the Channel. We thank the NASA for having provided free of charge NOAA AVHRR data and SeaWiFS colour data. Interpolation of the original swell significant heights has been done using the Surface Generator SurGe freeware provided by M. Dressler (http://www.geocities.com/miroslavdressler/surgemain.htm). Image processing (contrast enhancement, applying lookup table, legend insertion...) has been made using the ImageJ freeware provided by W. Rasband (http://rsb.info.nih.gov/ij). We also thank the two anonymous reviewers for valuable suggestions having improved the clarity of the paper. 


\section{References}

Baretta, J.W., Ebenhoh, W. and Ruardij, P., 1995. The European regional seas ecosystem model, a complex marine ecosystem model. Netherlands Journal of Sea Research, 33(3/4): 233-246.

Barnay, A. S., Ellien, C., Gentil, F. and Thiebaut, E., 2003. A model study on variations in larval supply: are populations of the polychaete Owenia fusiformis in the English Channel open or closed? Helgoland Marine Research, 56(4): 229-237.

Benoit, M. and Lafon, F., 2005. A nearshore wave atlas along the coasts of France based on the numerical modelling of wave climate over 25 years. Proc. 29th Int. Conf. on Coastal Eng.,Lisbon (Portugal), 19-24 September 2004, World Scientific Publ., pp 714726.

Brylinski, J.M., Brunet, C., Bentley, D., Thoumelin, G. and Hilde, D., 1996. Hydrography and phytoplankton biomass in the Eastern English Channel in spring 1992. Estuarine, Coastal and Shelf Science, 43(4): 507-519.

Brylinski, J.-M. and Lizon, F., 2002. Les larves de Polydora ciliata (Annélide Polychète) comme indicateurs biologiques de la dérive en Manche orientale. J. Rech. Oceanogr., 27(3-4): 219.

COMMON IMPLEMENTATION STRATEGY (CIS), 2002, Guidance on typology, reference conditions and classification systems for transitional and coastal waters produced by CIS Working Group 2.4 (COAST). 121 p.

Ellien, C., Thiébaut, E., Dumas, F., Salomon, J.-C. and Nival, P., 2004. A modelling study of the respective role of hydrodynamic processes and larval mortality on larval dispersal and recruitment of benthic invertebrates: example of Pectinaria koreni (Annelida: Polychaeta) in the Bay of Seine (English Channel). J. Plankton Res., 26(2): 117-132.

Gohin, F., Druon, J.N. and Lampert, L., 2002. A five channel chlorophyll concentration algorithm applied to SeaWiFS data processed by SeaDAS in coastal waters. International Journal of Remote Sensing, 8(23): 1639-1661.

Gohin, F., Loyer, S., Lunven, M., Labry, C., Froidefond, J.-M., Delmas, D., Huret, M. and Herbland, A., 2005. Satellite-derived parameters for biological modelling in coastal waters: Illustration over the eastern continental shelf of the Bay of Biscay. Remote Sensing of Environment, 95: 29-46.

Grioche, A., Koubbi, P. and Harlay, X., 1999. Spatial patterns of ichthyoplankton assemblages along the Eastern English Channel French coast during spring 1995. Estuar. Coast. Shelf Sci., 49(1): 141-152.

Grochowski, N.T.L., Collins, M.B., 1994. Wave activity on the sea-bed of the English Channel. J. Mar. Biol. Assoc. UK, 74: 739-742.

Guillaud J.-F., Ménesguen A., 1998. Modélisation sur vingt ans (1976-1995) de la production phytoplanctonique en Baie de Seine (France), Oceanol. Acta, 21(6): 887-906. 
Harrison W. G., Harris L. R., Irwin B. D., 1996. The kinetics of nitrogen utilization in the oceanic mixed layer: nitrate and ammonium interactions at nanomolar concentrations. Limnology and Oceanography, 41(1): 16-32.

Hoch, T. and Ménesguen, A., 1997. Modelling the biogeochemical cycles of elements limiting primary production in the English Channel. II. Sensitivity analyses. Mar. Ecol. Prog. Ser., 146: 189-205.

Holligan, P.M., Viollier, M., Dupouy, C., Aiken, J., 1983. Satellite studies on the distributions of chlorophyll an dinoflagellate blooms in the western English Channel, Continental Shelf Research, 2: 81-96.

Jolly, M., Viard, F., Weinmayr, G., Gentil, F., Thiébaut, E. and Jollivet, D., 2003. Does the genetic structure of Pectinaria koreni (Polychaeta: Pectinariidae) conform to a sourcesink metapopulation model at the scale of the Baie de Seine? Helgol. Mar. Res., 56(4): 238-246.

Lagadeuc, Y., 1992. Larval transport in the English Channel. Example of the annelid polychaete, Pectinaria koreni (Malmgren), in the Seine Bay. Oceanologica Acta, 15(4): 383-395.

Maguer, J.-F., Le Corre, P. and L'Helguen, S., 1996. Nitrogen sources for phytoplankton in shallow well-mixed waters of the western English Channel: Importance of the regenerated production: annual budget. J. Rech. Océanogr., 21(3-4): 103-108.

Ménesguen, A. and Hoch, T., 1997. Modelling the biogeochemical cycles of elements limiting primary production in the English Channel. I. Role of thermohaline stratification. Mar. Ecol. Prog. Ser., 146: 173-188.

Monod, J., 1950. La technique de culture continue. Théorie et applications. Ann. Inst. Pasteur, 79: 390-410.

Morin P., Le Corre P., Marty Y., L'Helguen S. 1991. Evolution printanière des éléments nutritifs et du phytoplancton sur le plateau continental armoricain (Europe du NordOuest). Oceanol. Acta, 14 (3): 263-279.

Orbi, A. and Salomon, J.C., 1988. Tidal dynamics in the vicinity of the Channel Islands. Oceanologica Acta, 11(1): 55-64.

O'Reilly, J. E., Maritorena, S., Mitchell, B.G., Siegel, D.A., Carder, K.L., Garver, S.A., Kahru, S.A., Mc Claim, C., 1998, Ocean color chlorophyll algorithms for SeaWiFS, Journal of Geophysical Research, 103(CII): 24,937-24,953.

Pingree, R. D., 1980. Physical oceanography of the Celtic Sea and English Channel. In: Banner F.T., Collins M.B. and Massie K.S. (Eds), The North West European Shelf Sea: the bed and the sea in motion. 2. Physical and chemical oceanography and physical resources., Elsevier Oceanog. Ser., pp. 415-465. 
Pingree, R.D., Holligan, P.M. and Mardell, G.T., 1979. Phytoplankton growth and cyclonic eddies. Nature, 278: 245-247.

Pingree, R.D., Maddock L., 1985. Stokes, Euler and Lagrange aspects of residual tidal transports in the English Channel and the Southern Bight of the North Sea. Journal of the Marine Biological Association of the United Kingdom, 65(4): 969-982.

Pingree, R.D., Mardell, D.T. and Maddock, L., 1985. Tidal mixing in the Channel Isles region derived from the results of remote sensing and measurements at sea. Estuarine, Coastal and Shelf Science, 20: 1-18.

Salomon, J.C. and Breton, M., 1991. Courants résiduels dans la Manche. Oceanologica Acta, special issue $n^{\circ} 11: 47-53$.

Salomon, J.C. and Breton, M., 1993. An atlas of long term currents in the Channel. Oceanologica Acta, 16: 439-448.

Savina, M., 2004. Modélisation écologique des populations de palourdes roses (Paphia rhomboïdes) et d'amandes de mer (Glycymeris glycymeris) en Manche. Thèse de doctorat de l'université d'Aix-Marseille II, France, 191 pp.

Simpson, J.H. and Hunter, J.R., 1974. Fronts in the Irish Sea. Nature, 1250: 404-406.

Vaslet, D., Larsonneur, C. and Auffret, J.-P., 1978. Les sédiments superficiels de la Manche 1/500000. Carte géologique de la marge continentale française. Ministère de l'industrie - Bureau de recherches géologiques et minières.

Velegrakis, A.F., Michel, D., Collins, M.B., Lafite, R., Oikonomou, E.K., Dupont, J.P., Huault, M.F., Lecouturier, M., Salomon, J.C. and Bishop, C., 1999. Sources, sinks and resuspension of suspended particulate matter in the eastern English Channel measurements and prediction. Continental Shelf Research, 19(15): 1933-1957.

Viollier, M., Sournia, A., Birrien, J.-L. and Morin, P., 1987. Observations satellitaires du phytoplankton dans les zones de discontinuité hydrologique au large de la Bretagne. Actes du Colloque Océanographie Spatiale, Brest, 19-20 Novembre 1985, Oceanologica Acta, 7: 51-56.

Vollenweider, R.A., 1975. Input-output model with special reference to the phosphorus loading concept in limnology. Z. Hydrobiol., 37: 53-84. 


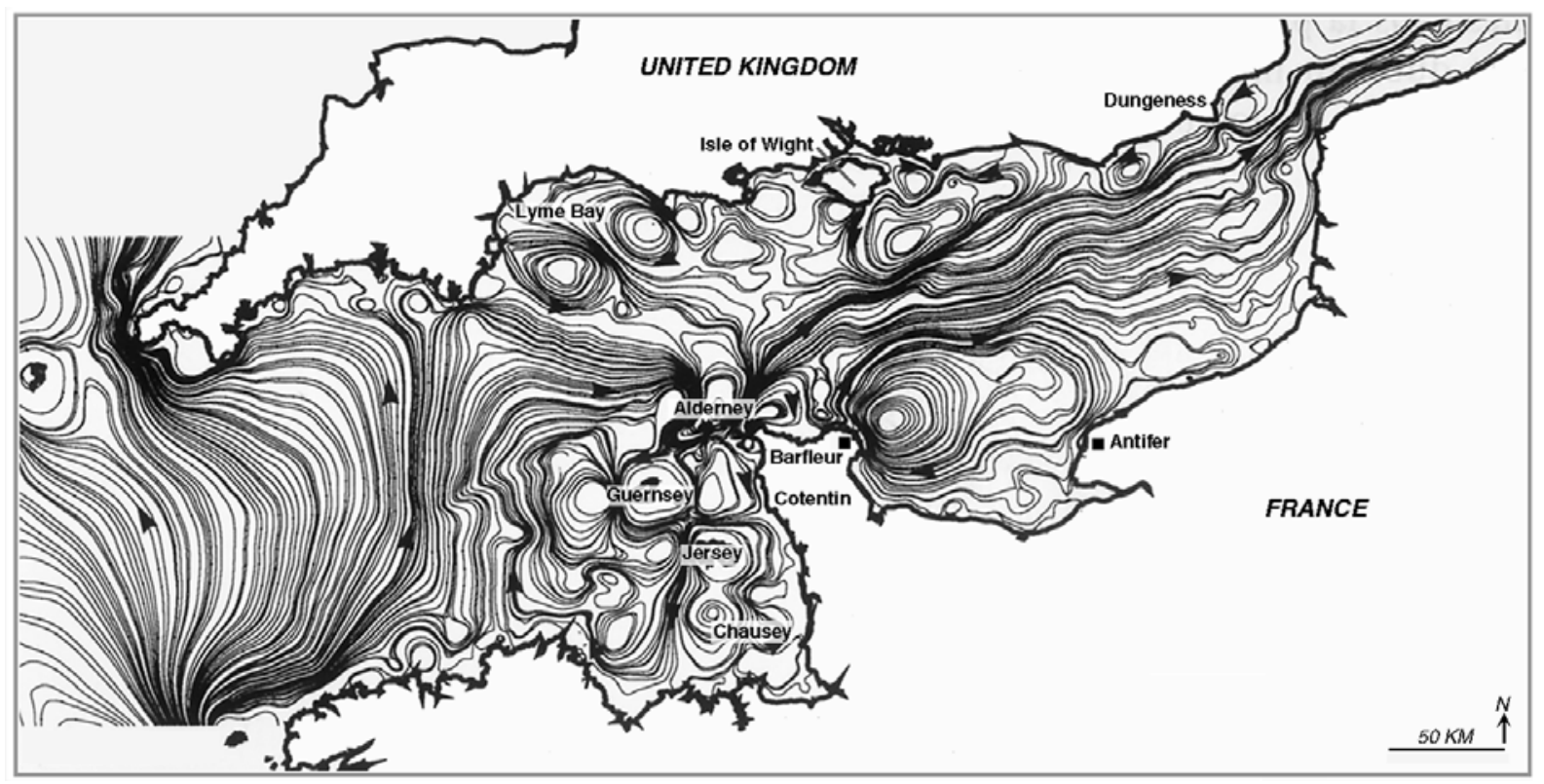

Figure 1. Streamlines of tidal residual flow in the English Channel, computed for a constant medium tidal amplitude and without wind (from Salomon and Breton, 1991). 


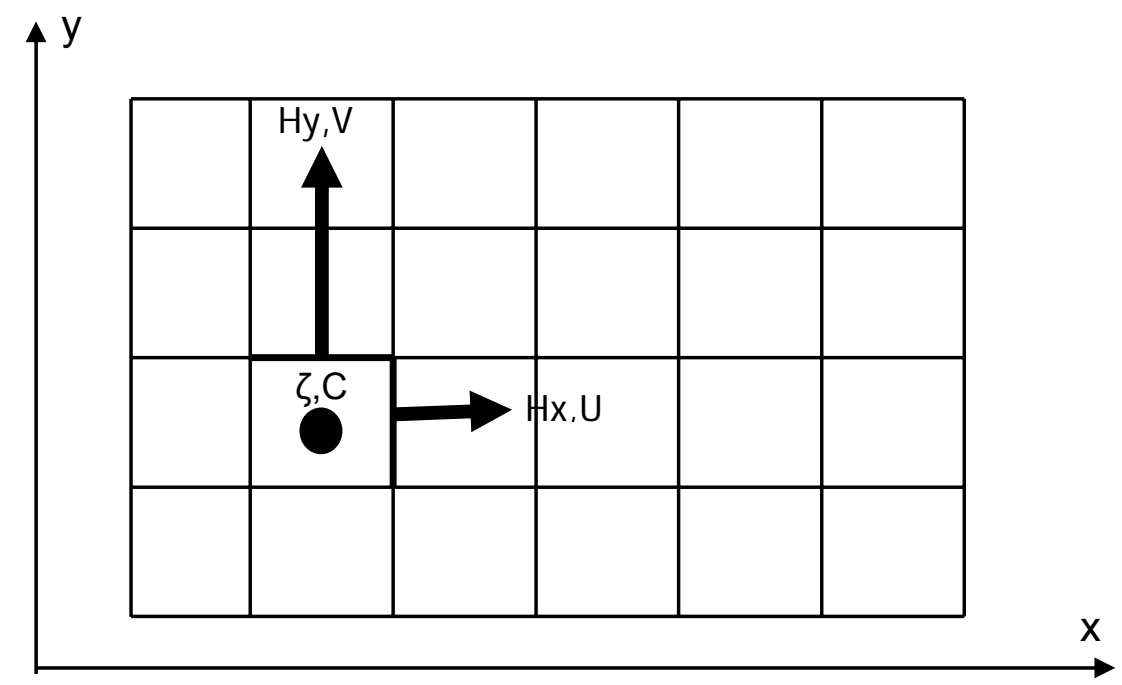

Figure 2. Sketch of the Arakawa-C grid used for 2DH Mars model. 


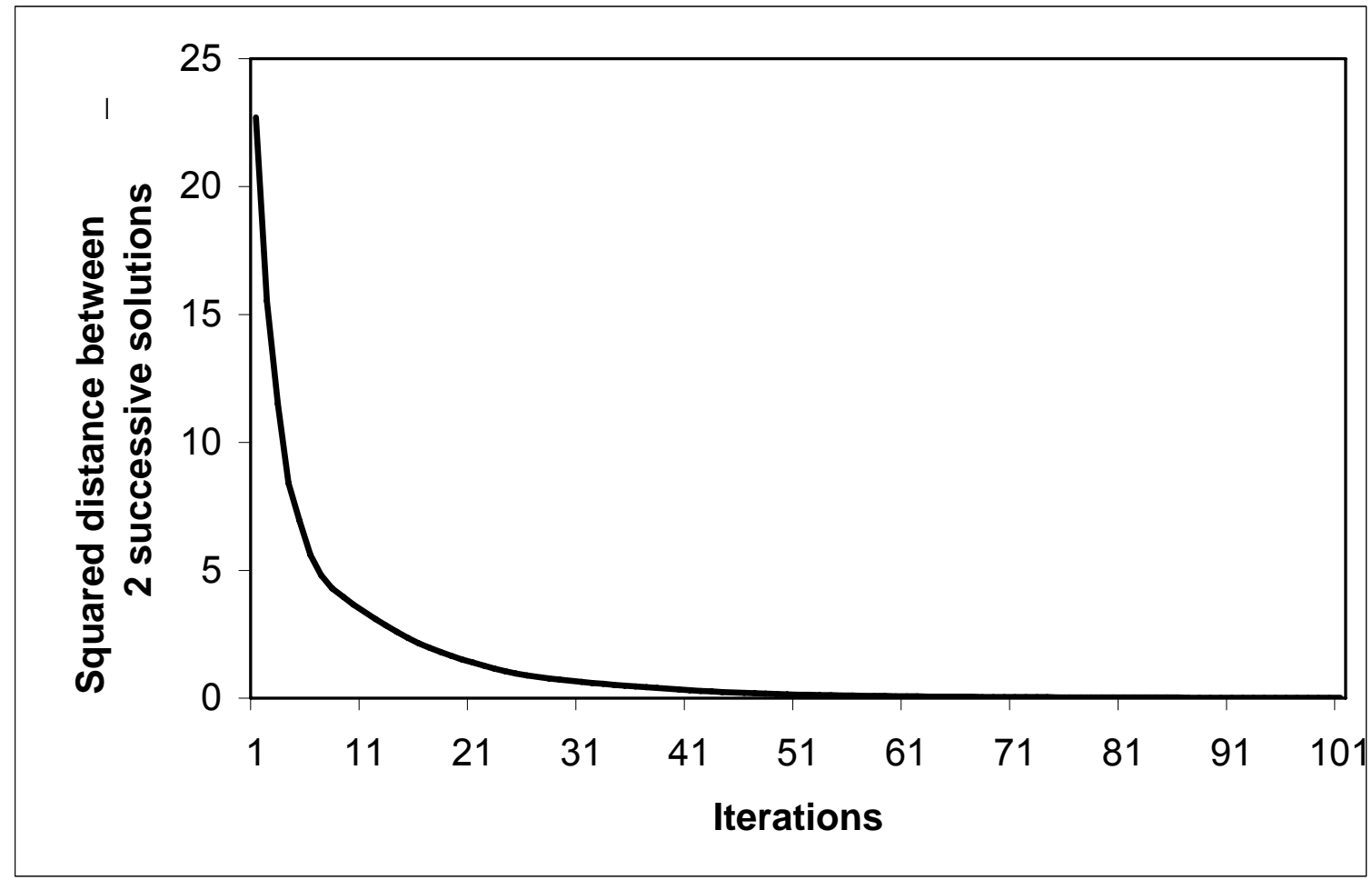

Figure 3. Convergence of the iterative method of big linear system solving, measured by the squared Euclidian distance between two successive solution vectors Cequil. 


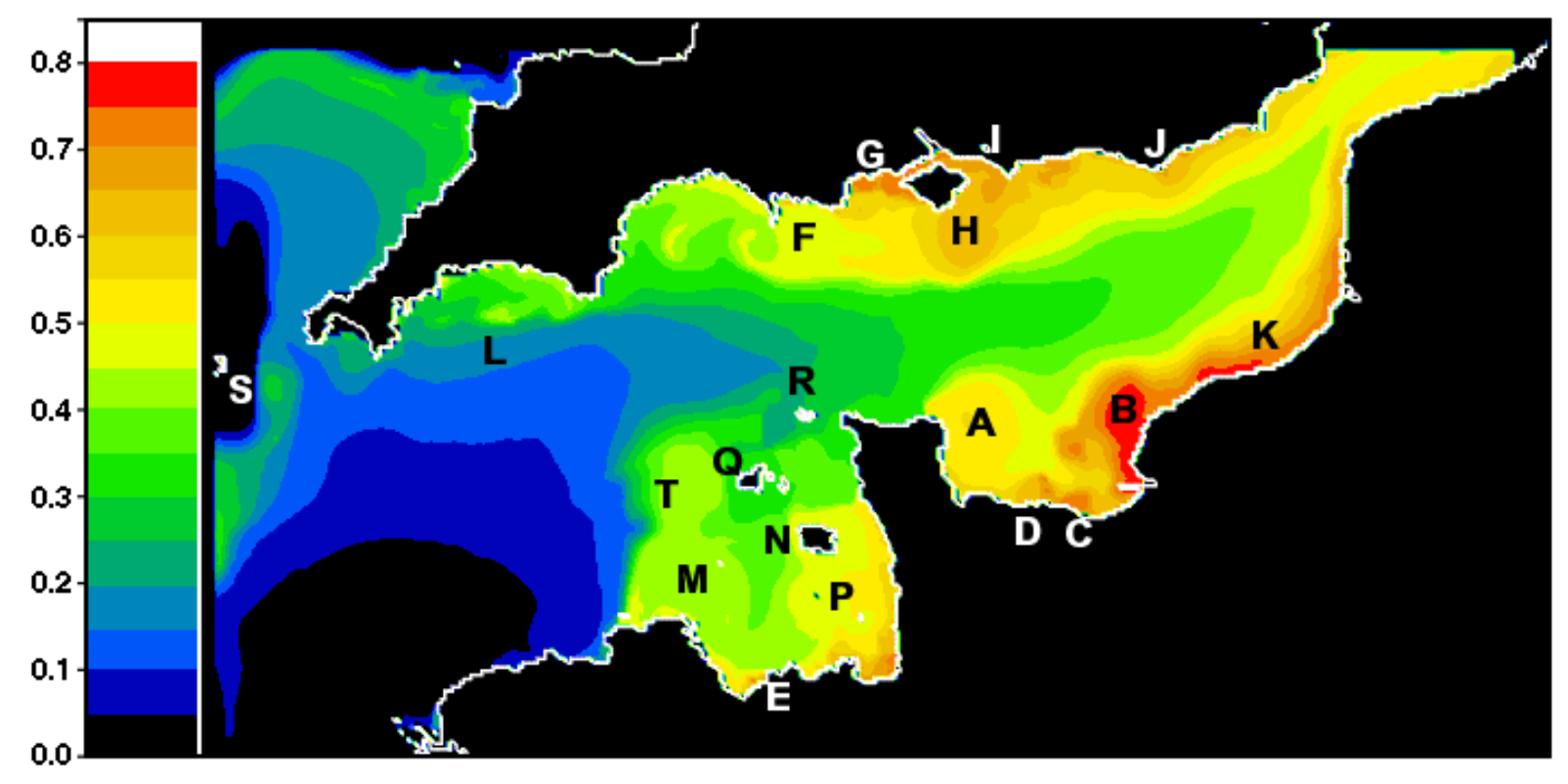

Figure 4. Steady state distribution of a pure conservative tracer injected homogeneously all over the model grid. 


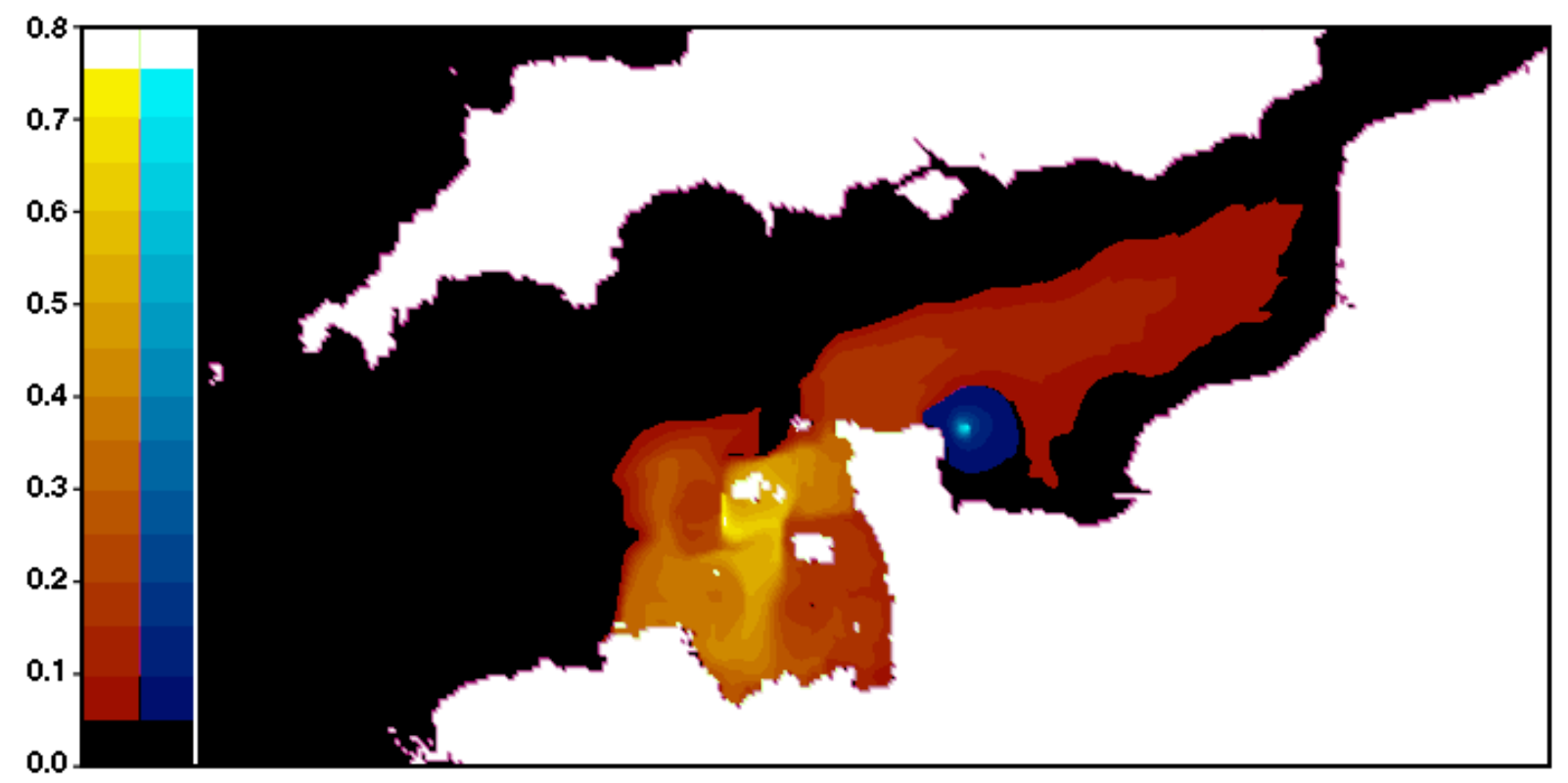

Figure 5. Steady state distribution of a pure conservative tracer injected only in one mesh: red spectrum is associated to a mesh located in the Guernsey gyre, blue spectrum to a mesh located in the centre of the Barfleur gyre. 


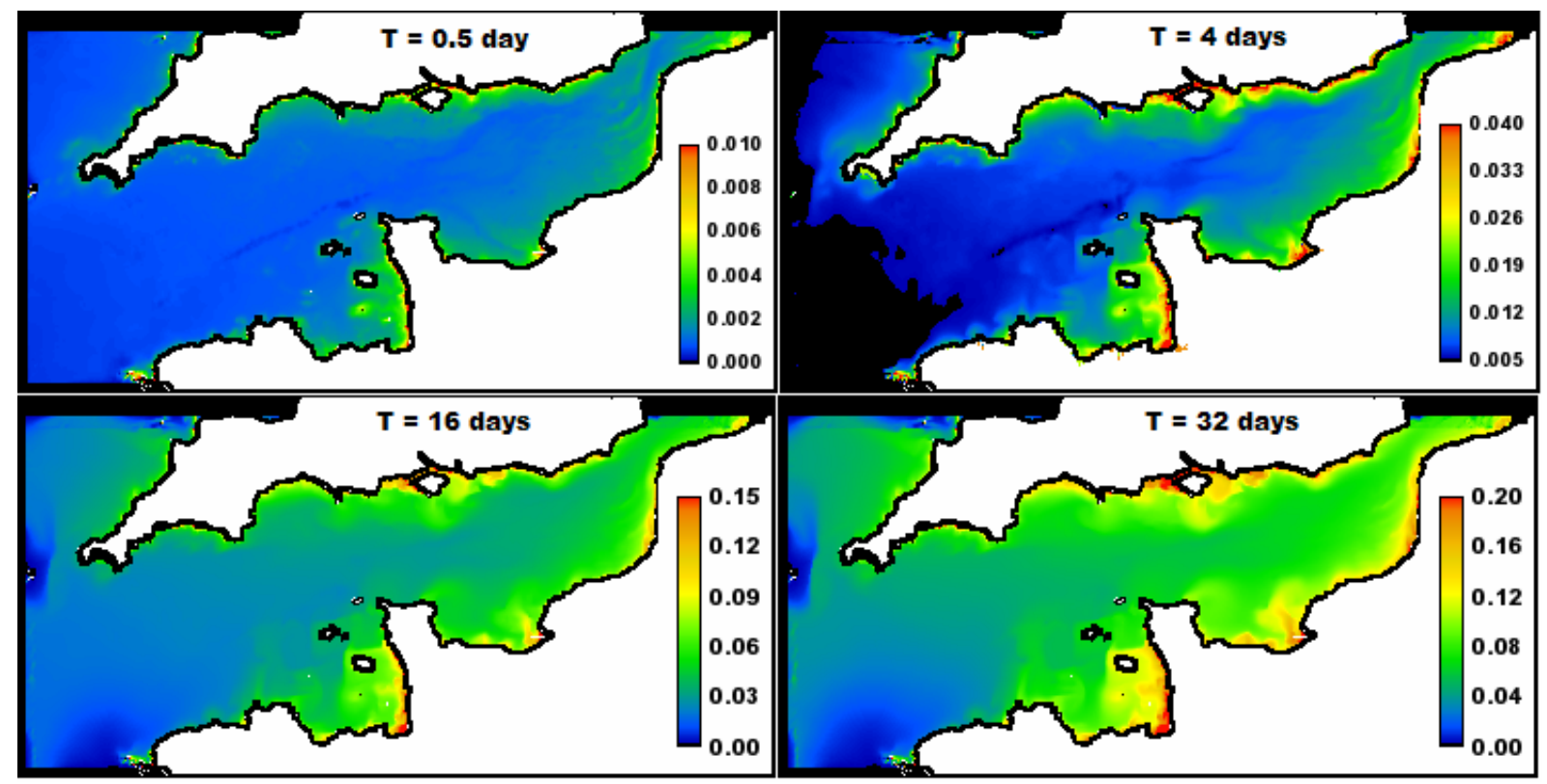

Figure 6. Steady state distribution of 4 tracers with increasing half-life constants T, injected homogeneously all over the model grid. 


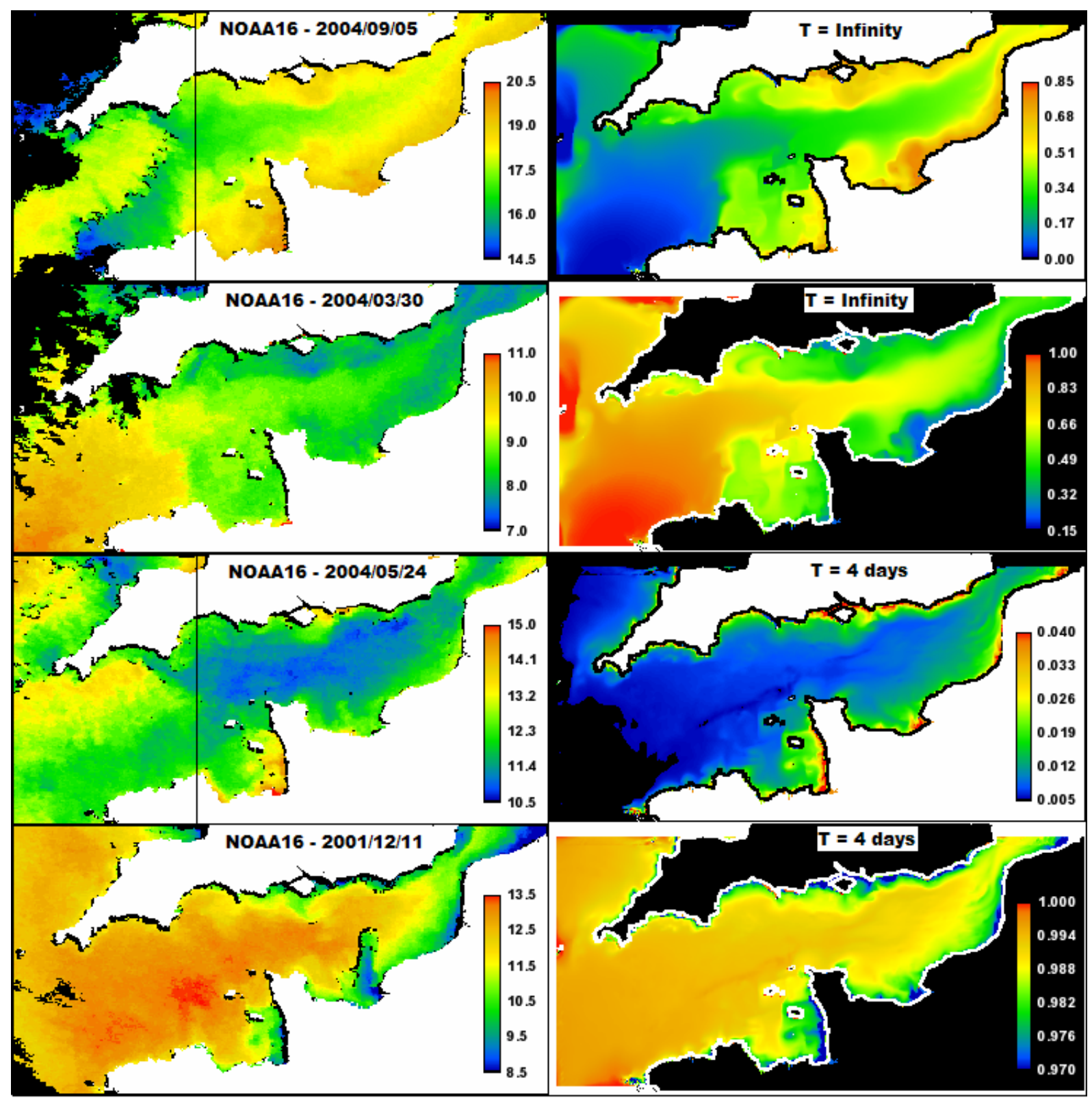

Figure 7. Seasonal distribution of Sea Surface Temperature (SST). From top to bottom: at the end of summer, at the end of winter, in the middle of spring, in the middle of autumn. Left column: SST images obtained by the infrared AVHRR sensor aboard NOAA satellites, Right column: steady state distributions of tracers injected homogeneously all over the model grid and having best-fitted half-life durations $\mathrm{T}$ as indicated. The vertical line on spring and summer satellite views splits the Channel into a western stratified part and a vertically mixed eastern part: in this case, correlation between satellite image and model were performed on the eastern part only. The scale is linear for each sub-figure, in degrees Celsius for satellite images, in arbitrary unit for tracer computed distributions. 


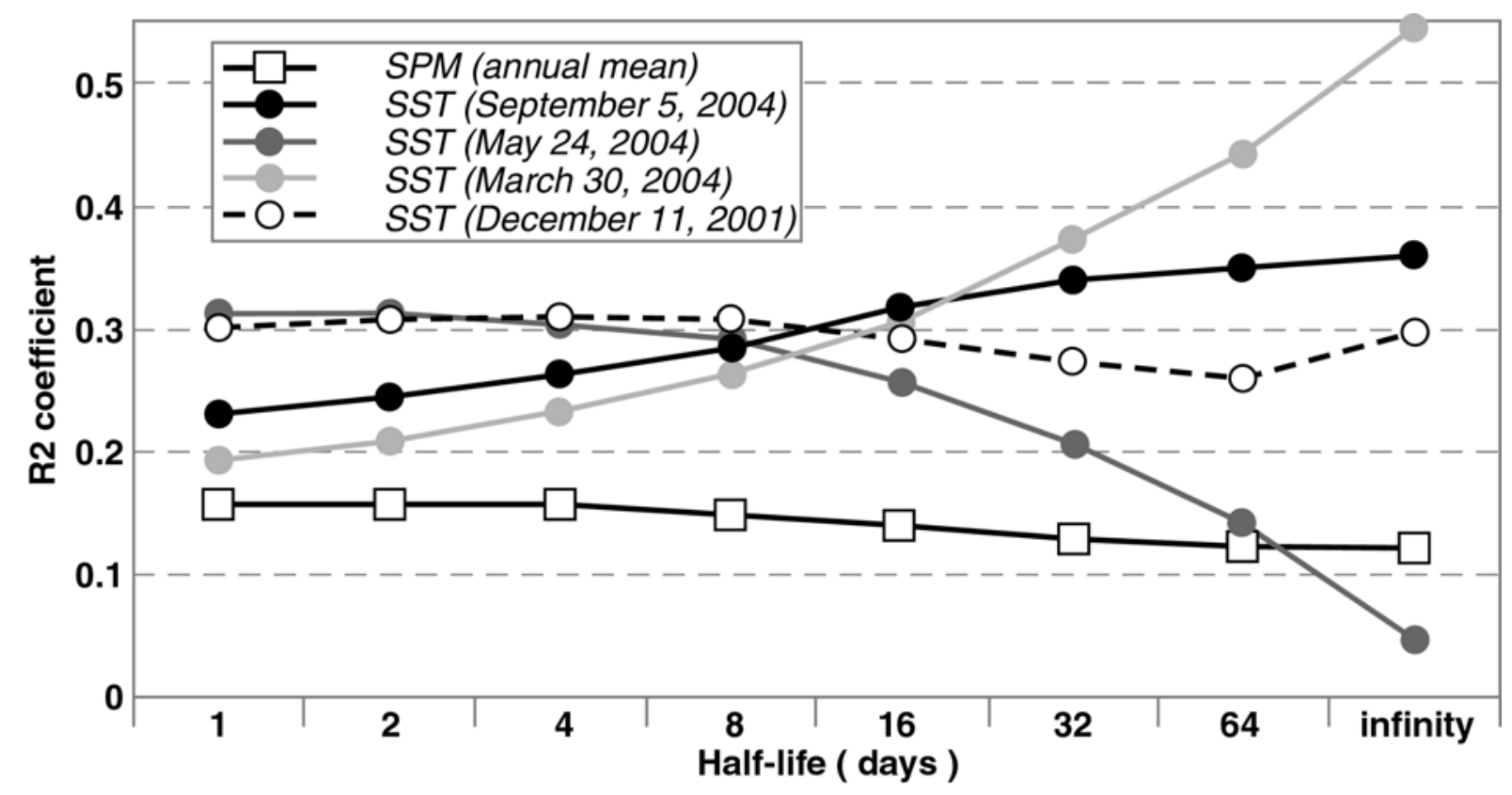

Figure 8. Variations of the linear correlation between observed SST maps and computed steady state maps of tracers with increasing half-life durations. 


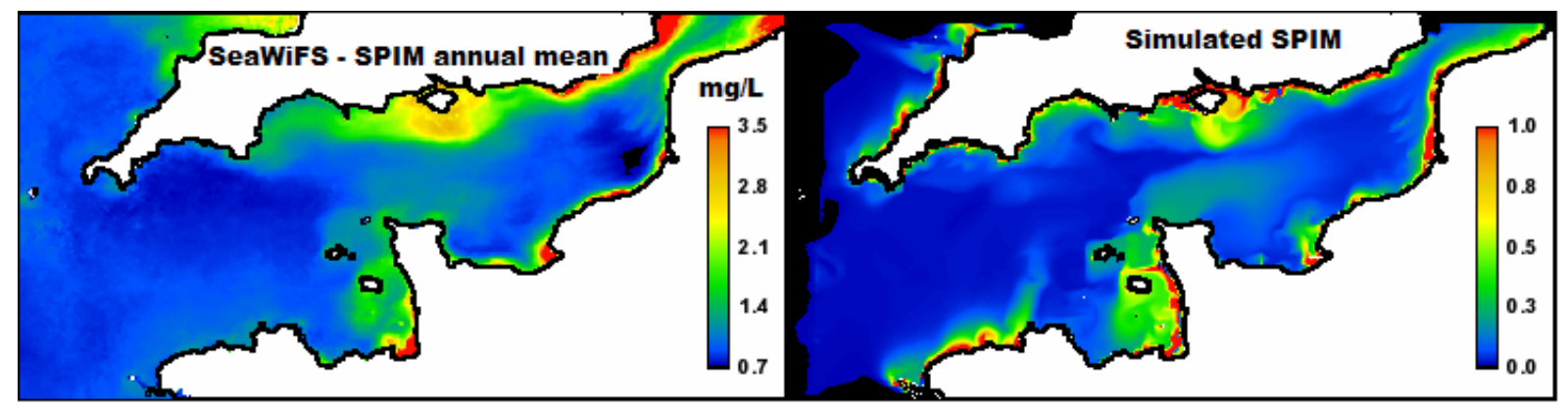

Figure 9. Annual mean distribution of Suspended Particulate Inorganic Matter (SPIM). Left: annual mean composite obtained from clear existing SeaWiFS images (mg/L), Right: steady state distribution of a tracer injected in every mesh following local silt fraction of the sediment and swell mean stress and experiencing space-variable half-life durations, following the local vertical mixing capability (arbitrary unit). 


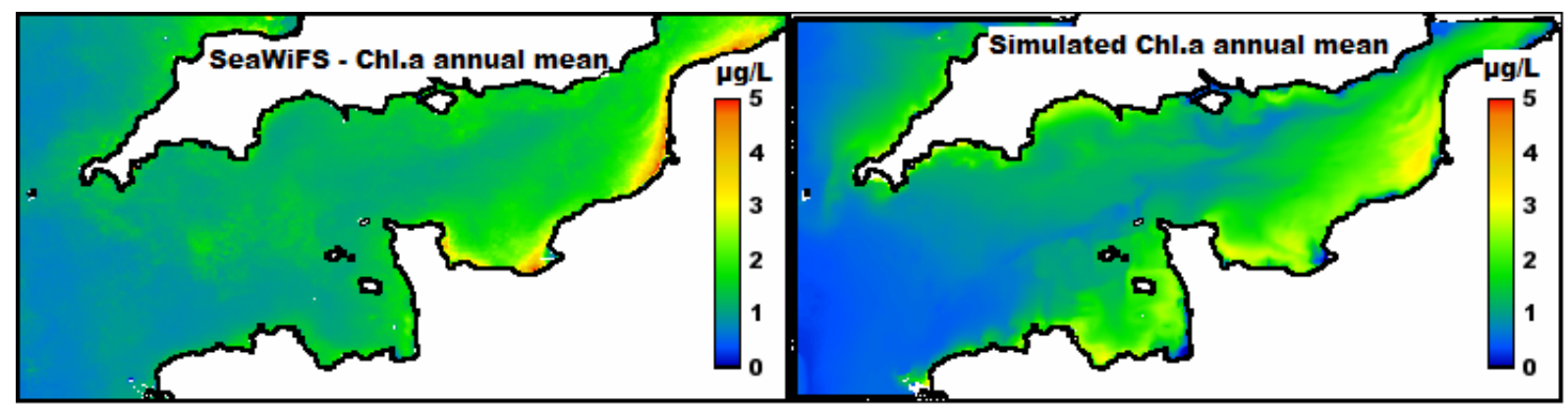

Figure 10. Annual mean distribution of Chlorophyll (Chl). Left: annual mean composite obtained from clear existing SeaWiFS images, Right: steady state distribution of a tracer injected in every mesh following local light availability in the water column and experiencing a mortality made of a uniform component (half-life $=4$ days) and a locally varying component inversely proportional to the water depth. Both maps are expressed in $\mu \mathrm{g} . \mathrm{L}^{-1}$ Chl.a. 